\title{
Flashing green effects on traffic efficiency
}

\author{
Anica Kocića ${ }^{\star}$, Nikola Čelara, Jelena Kajalića , Stamenka Stankovića \\ a Faculty of Transport and Traffic Engineering, University of Belgrade, Vojvode Stepe 305, Belgrade, Serbia
}

\begin{tabular}{|c|c|}
\hline ARTICLE INFO & A B S TRACT \\
\hline $\begin{array}{l}\text { DOI: } 10.31075 / \text { PIS.66.02.05 } \\
\text { Professional paper } \\
\text { Received: } 19.03 .2020 \\
\text { Accepted: } 10.06 .2020 \\
\text { Corresponding author: } \\
\text { a.kocic@sf.bg.ac.rs } \\
\text { Keywords: } \\
\text { Flashing green } \\
\text { Traffic efficiency } \\
\text { Effective green } \\
\text { Signalized intersection }\end{array}$ & $\begin{array}{l}\text { Flashing green signal, as a part of the green traffic signal, indicates that the green } \\
\text { signal is about to end. Drivers have more time to decide whether to stop or pass } \\
\text { the intersection since they have prior information that the yellow signal will start. } \\
\text { The application of flashing green at the end of the green signal is optional, hence, } \\
\text { the question is how engineers could decide to use flashing green or not? The } \\
\text { answer to the question should be based on researches on flashing green effects } \\
\text { on traffic efficiency and safety at signalized intersections. The aim of this paper } \\
\text { is to analyze the impact of flashing green on traffic efficiency by determining the } \\
\text { value of effective green time. The research was conducted at two intersections in } \\
\text { Belgrade, with and without a flashing green signal. Results indicate that effective } \\
\text { green is shorter when flashing green is applied, due to the decreased utilization } \\
\text { of the yellow signal. }\end{array}$ \\
\hline
\end{tabular}

\section{Introduction}

Traffic signal transition from green to yellow affects driving behavior change because drivers should decide whether to stop or pass the intersection until the red signal starts. Flashing green signal, as a part of the green traffic signal, indicates that the green signal is about to end. Since drivers have prior information that the yellow signal will start they have more time to decide whether to stop or pass the intersection. On the other hand, if flashing green is not applied, drivers have information about green signal ending when the yellow signal starts. In such situations, drivers often don't have enough time to stop safely, so they cross the stop line at the red signal beginning.

The application of flashing green at the end of the green signal is optional, hence, the question is how engineers could decide to use flashing green or not. The answer to the question should be based on researches on flashing green effects on traffic efficiency and safety at signalized intersections. Previous related studies are mainly based on traffic safety effects, so there is a lack of traffic efficiency effects researches. This paper aim is to analyze the impact of flashing green on traffic efficiency by determining the value of yellow signal utilization, as a part of effective green time.

\section{Literature review}

As Akçelik (1981) describes, the queue discharge begins after the green signal start and the discharge rate increases to a saturation flow rate and remains constant until the queue is exhausted or the green period ends.

The discharge rate is lower during the first few seconds of green time while vehicles accelerate to normal running speed. This period represents a start-up lost time a (s). Also, the discharge rate is lower during the period after the green signal change to yellow because some vehicles stop and others do not. So, this period represents yellow signal utilization $b$ (s). Figure 1 illustrates the previously described process if queue persists until the green signal end.

According to the described process, the start-up lost time and the yellow signal utilization values represent a difference between green time and effective green time. Since capacity, as one of the effectiveness measures, directly depends on effective green time, there is an expectation that shorter yellow signal utilization leads to lower capacity. This relation is given by Equation 1. Therefore, flashing green impact on traffic efficiency can be evaluated through the value of yellow signal utilization. 


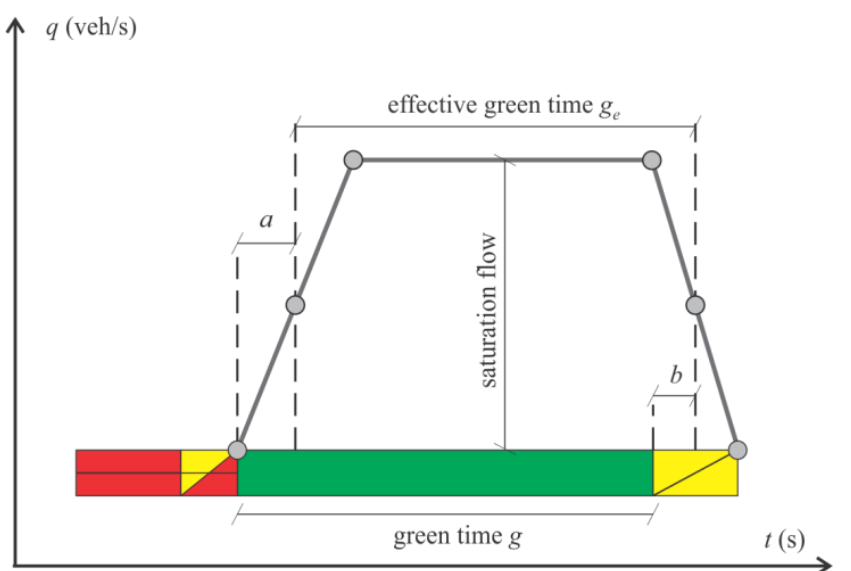

Figure 1. Saturation flow base model

Source: Čelar, et al. 2018

$$
C=S \cdot \frac{g_{e}}{c}=S \cdot \frac{g+b-a}{c}
$$

where:

C - capacity (veh/h),

$S$ - saturation flow rate (veh/h),

$g_{e}$ - effective green time $(\mathrm{s})$,

$c$ - cycle length (s),

$g$ - green time (s),

a - start-up lost time (s),

$b$ - yellow signal utilization (s).

The researches on flashing green signal effects are mainly based on traffic safety effects. Results of first studies on flashing green effects in Israel and Austria showed that flashing green application reduces the percentage of red light violations and decreases rightangle collisions number (Becker, 1971; Knoflacher, 1973; Hakkert \& Mahalel, 1978). On the other hand, previously mentioned studies showed increasing in rear-end collisions number.

In Mahalel, et al. (1985) study, short videos representing various situations on signalized intersections with and without a flashing green were showed to drivers to analyze their behavior during traffic signal transitions from green to red. It was found that the flashing green elicited from the drivers an earlier decision response and a higher number of inappropriate stopping decisions. The pattern of stopping and crossing decisions with the flashing green signal suggests a higher likelihood of rear-end collisions than without the flashing green.

Drivers' stopping behavior during signal programs with and without flashing green was analyzed and modeled based on researches in Switzerland, Austria, and Germany (Köll, et al. 2004). The analysis shows that the flashing green increases the number of early stops which should reduce the likelihood of right-angle collisions. On the other hand, the flashing green in Austria produces a large option zone which generates a period of uncertainty and could lead to an increased number of rear-end collisions.
Factor, et al. (2012) conducted a survey among Israeli drivers to evaluate perceptions of the flashing green interval, knowledge of its legal meaning, perceived safety implications and behavior on flashing green. Results showed that people support the use of the flashing green phase. At the same time, people do not entirely understand the meaning of the flashing green or know how to behave in its presence. As a result, sometimes they stop and sometimes they accelerate, making their actions difficult for others to anticipate.

Shen \& Wang (2015) explored the effects of flashing green on drivers in China by comparing the vehicles' behavior before and after the flashing green start. Results indicate that flashing green is an effective way to prevent yellow signal running, but only installing flashing green cannot improve the safety of intersections, though it can provide more information to the drivers.

Impacts of flashing green on dilemma zone behavior at the high-speed intersections with insufficient yellow interval were investigated in Shanghai, China (Tang, et al. 2015). Flashing green signal might be efficient in preventing right-angle collisions by reducing the occurrence of dilemma zone type I. However, it may also lead to more rear-end collisions by creating large decision variations both at the onset of flashing green and yellow. The vast majority of drivers reacted to the onset of flashing green, instead of yellow onset.

Later, Tang, et al. (2016) analyzed and modeled the drivers' stop-go decision behavior at rural high-speed intersections in China, where a flashing green signal of 3 s followed by a yellow signal of $3 \mathrm{~s}$. It was found that the presence of flashing green considerably increased the conservative stops by $14.2 \%$, slightly induced the aggressive passes by $2.3 \%$, and thus remarkably changed the theoretical decision zones based on the conventional theory. Binary Logistic models and Fuzzy Logic models were developed to further explore the impacts of flashing green on the stop-go behavior of drivers.

The general characteristics of stop-line crossing time and speed during flashing green and yellow signals were analyzed at two types of intersections in Shanghai, China (Tang, et al. 2017). Then, a multinomial logit model and a multiple linear regression model were developed to predict the stop-line crossing patterns and speeds respectively. It was found that the percentage of stop-line crossings during the yellow interval is remarkably higher at the urban intersections than at the rural intersections. Also, the stop-line crossing time is approximately $0.7 \mathrm{~s}$ longer at the urban intersections. Besides, approaching speed and distance to the stop-line at the onset of flashing green as well as area type significantly affect the percentages of stop-line crossings during the flashing green and yellow intervals. Vehicle type and stop-line crossing pattern were found to significantly influence the stopline crossing speed, too. 
In summary, most of the studies concluded that the flashing green application leads to increasing the number of rear-end collisions although it reduces redlight violations and the number of right-angle collisions. These conclusions represent the effects of flashing green on traffic safety, however, effects on traffic efficiency weren't considered.

Despite the neglect of the efficiency aspect, previous studies highlighted some important results as an increase in the number of early stops when flashing green is applied. Hence, this research hypothesis is that yellow signal utilization will be shorter when flashing green is present due to confirmed earlier stops.

However, value of the yellow time utilization was researched on more than 300 lanes at 40 intersections in Belgrade (Stanković, et al. 2016). The main objective of this research was to analyze the influence of green time ratio and degree of saturation on the yellow time utilization value, but without consideration of the flashing green signal effects.

\section{Research methodology}

The research was conducted at two intersections in Belgrade, with and without flashing green signal, to determine a difference in yellow signal utilization when flashing green is applied and not. Intersections are along Vojislava Ilića Street with similar traffic and geometry characteristics, given in Table 1. Figure 2 shows intersections' micro-location.

Table 1. Intersections' characteristics

\begin{tabular}{|l|c|c|}
\hline Intersection & $\begin{array}{c}\text { Without flashing } \\
\text { green }\end{array}$ & $\begin{array}{c}\text { With flashing } \\
\text { green }\end{array}$ \\
\hline Approach & Northbound & Northbound \\
\hline Lane Configuration & $\mathrm{L}, \mathrm{T}, \mathrm{TR}$ & $\mathrm{L}, \mathrm{T}, \mathrm{TR}$ \\
\hline Cycle length (s) & 75 & 101 \\
\hline Green time (s) & 35 & 43.5 \\
\hline Flashing green time (s) & - & 2.5 \\
\hline Yellow time (s) & 3 & 3 \\
\hline Green time ratio (-) & 0.47 & 0.46 \\
\hline$\%$ passenger car & 85.5 & 86.6 \\
\hline
\end{tabular}

$\mathrm{L}=$ left-turn lane, $\mathrm{T}=$ through lane, $\mathrm{TR}=$ shared through and rightturn lane

Left and right movements aren't relevant for this research due to vehicle deceleration caused by path deflection. Hence, only vehicles in through lanes are considered during the traffic signal transition from green to red. Traffic conditions at intersections shouldn't be saturated or oversaturated, but queue should persist until the green signal end due to the research objective.

Video technique was used for data collecting at both intersections and the camera was located so that traffic signals and vehicles can be recorded simultaneously. Data were collected during two weekdays, 10th and 11th of September, 2019, in the afternoon peak hour 16.00 - 18.00h. After analyzing the videos, 33 relevant cycles at each intersection were selected.
Only first-to-stop and last-to-go passenger car vehicles were analyzed to determine the yellow signal utilization values. Trucks and buses were excluded from analysis due to the small sample and different maneuver characteristics. Yellow signal utilization value was determined as a difference between the time of the lastto-go vehicle across the stop line and the time of the yellow signal start.

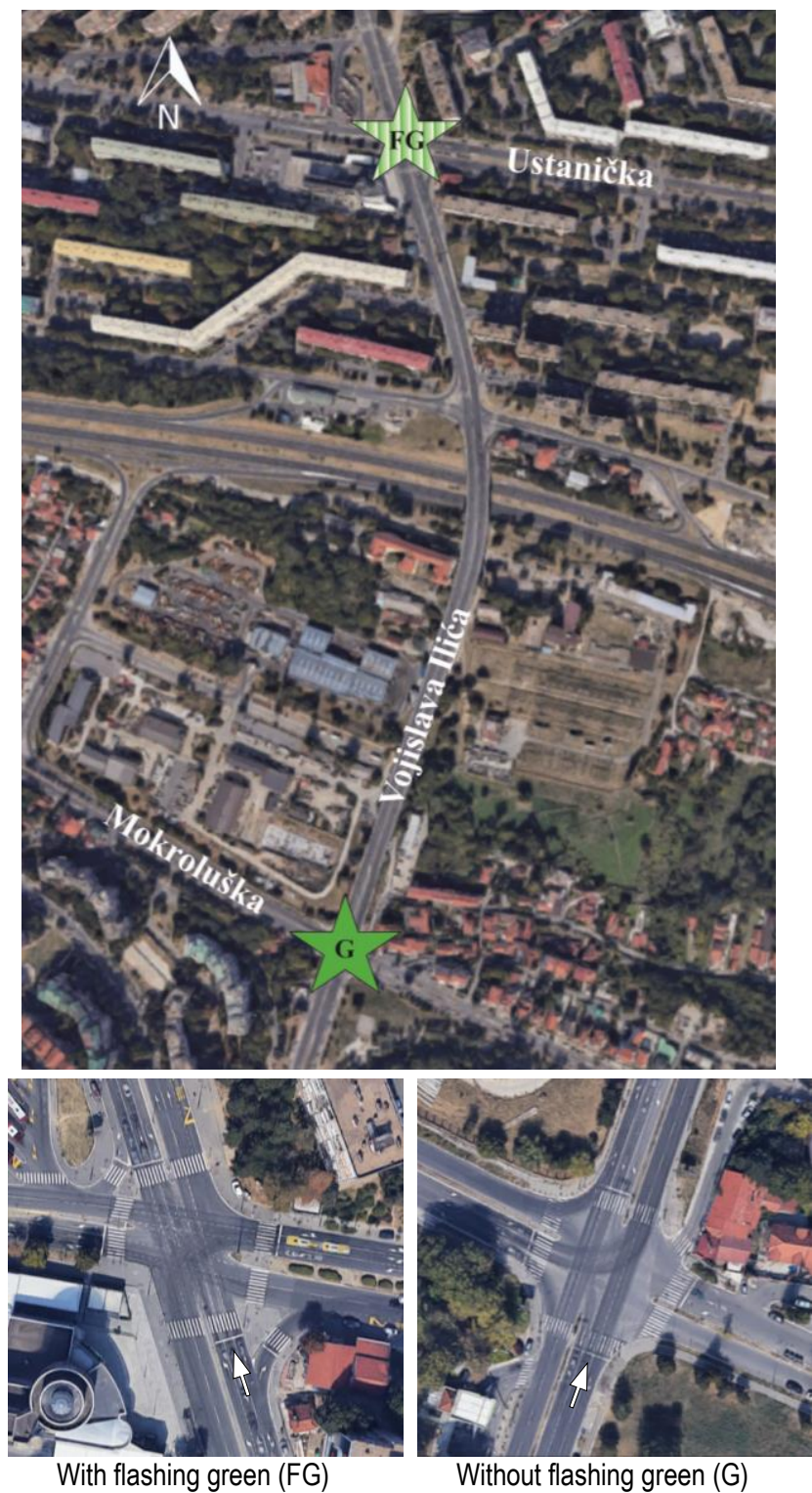

Figure 2. Intersections' micro-location

\section{Results and discussion}

Data of the selected 66 cycles are analyzed and results are given in Table 2. The average yellow signal utilization is $1.57 \mathrm{~s}$ and $3.27 \mathrm{~s}$ when flashing green is applied and not, respectively. So, the conclusion is that the average yellow signal utilization is shorter when flashing green is applied. Therefore, this paper's hypothesis is confirmed. Also, with an assumption that the start-up lost time is equal, decreased yellow signal utilization implies that the effective green time is lower for $1.70 \mathrm{~s}$ if flashing green is applied. 
Table 2. Yellow signal utilization at intersections with and without flashing green signal

\begin{tabular}{|l|c|c|}
\hline Intersection & $\begin{array}{c}\text { Without flashing } \\
\text { green }\end{array}$ & $\begin{array}{c}\text { With flashing } \\
\text { green }\end{array}$ \\
\hline $\mathbf{N}$ & 33 & 33 \\
\hline Average $\boldsymbol{b}$ (s) & 3.27 & 1.57 \\
\hline Standard deviation (s) & 1.52 & 1.07 \\
\hline Minimum $\boldsymbol{b}$ (s) & 0.07 & -0.52 \\
\hline Maximum $\boldsymbol{b}$ (s) & 6.36 & 3.9 \\
\hline
\end{tabular}

The average value of the yellow signal utilization is 3.27 $\mathrm{s}$ with a standard deviation of $1.52 \mathrm{~s}$ if flashing green isn't applied. The result indicates that drivers use the entire length of the yellow signal, and even a part of the red signal, for passing the intersection. As it is shown in Table 3,55\% of drivers cross the stop line during the red signal, if flashing green is not applied. On average they use $1.36 \mathrm{~s}$ and a maximum $3.36 \mathrm{~s}$ of the red signal. In such situations, right-angle collisions may occur if a red clearance interval is short. On the other hand, it has a positive effect on traffic efficiency because an effective green time is longer than a green time. Reasons for red light violations could be late information that green time is about to end so drivers can't stop safely or overestimation of remaining time after the yellow signal starts for passing the intersection.

Table 3. Drivers' behavior on the green signal end

\begin{tabular}{|l|c|c|c|c|}
\hline Intersection & \multicolumn{2}{|c|}{$\begin{array}{c}\text { Without flashing } \\
\text { green }\end{array}$} & \multicolumn{2}{|c|}{$\begin{array}{c}\text { With flashing } \\
\text { green }\end{array}$} \\
\hline Stopping on flashing green & - & - & 4 veh. & $12 \%$ \\
\hline $\begin{array}{l}\text { Average value of green } \\
\text { signal unused part (s) }\end{array}$ & \multicolumn{2}{|c|}{-} & \multicolumn{2}{|c|}{-0.29} \\
\hline $\begin{array}{l}\text { Stop line passages during } \\
\text { yellow }\end{array}$ & 15 veh. & $45 \%$ & 27 veh. & $82 \%$ \\
\hline $\begin{array}{l}\text { Average } \text { b for passages } \\
\text { during yellow signal (s) }\end{array}$ & \multicolumn{2}{|c|}{1.96} & \multicolumn{2}{|c|}{1.70} \\
\hline $\begin{array}{l}\text { Stop line passages during } \\
\text { red }\end{array}$ & 18 veh. & $55 \%$ & 2 veh. & $6 \%$ \\
\hline $\begin{array}{l}\text { Average } \text { b for passages } \\
\text { during red signal (s) }\end{array}$ & \multicolumn{2}{|c|}{4.36} & \multicolumn{2}{|c|}{3.50} \\
\hline
\end{tabular}

If flashing green is applied, the average yellow signal utilization is $1.57 \mathrm{~s}$ with a standard deviation of $1.07 \mathrm{~s}$. This result indicates that about half of the yellow signal is used for passing the intersection. Based on results in Table 2, minimum yellow signal utilization is $-0.52 \mathrm{~s}$, meaning that some drivers decide to stop on flashing green. Precisely, $12 \%$ of drivers stop during the flashing green signal, on average $0.29 \mathrm{~s}$ before its end (Table 3). This indicates that effective green time is shorter than green time due to the unused $0.29 \mathrm{~s}$ of green and $3 \mathrm{~s}$ of yellow signal, although drivers can pass the intersection legally and safely. As it is concluded in literature, earlier stops are recorded when flashing green is applied. Only $6 \%$ of drivers pass the stop line after the red signal start using $0.5 \mathrm{~s}$ of the red signal, on average.

\section{Conclusion}

Flashing green signal application is optional in Serbia, so traffic signal sequence at some intersections is red - red/yellow - green - yellow and at others, it is red red/yellow - green - flashing green - yellow. Recently, flashing green is applied more often and the question is how engineers decide to implement a flashing green signal. Is it a trend or is this decision made based on established flashing green effects on traffic efficiency and safety?

According to the relevant literature, there are some positive and some negative effects of flashing green signal on traffic safety. Positive effects are the reduction of red light violations and right-angle collisions, due to the dilemma zone length decreasing. On the other hand, a negative effect is increasing of optional zone length, so drivers' decisions may conflict with each other which leads to an increase in the rearend collisions number. Also, it was concluded that flashing green effects on traffic efficiency isn't analyzed. However, due to confirmed earlier stops, this research hypothesis was that yellow signal utilization will be shorter when flashing green is present.

Results showed that yellow signal utilization is shorter if flashing green is applied than if it's not, on average for $1.70 \mathrm{~s}$. This result confirms the paper's hypothesis and indicates that effective green is shorter if flashing green is applied which contributes to lower capacity value. As well, even $12 \%$ of drivers stopped before the flashing green end at the intersection with a flashing green signal.

Also, it was showed that flashing green presence affects the reduction of crossing a stop line during the red signal, as previous studies concluded (Becker, 1971; Knoflacher, 1973; Hakkert \& Mahalel, 1978; Mahalel, et al. 1985; Köll, et al. 2004; Tang, et al. 2016). Namely, $55 \%$ of drivers pass an intersection during first few seconds of the red signal if flashing green is not applied. Probably, it happens because drivers have late information that the green signal ends so they don't have time to stop safely or they overestimate remaining time until the red signal start. On the other hand, only $4 \%$ of drivers cross the stop line after the red signal start if flashing green is implemented, due to earlier information that red signal starts soon.

This research shows the initial results of the flashing green effects on traffic efficiency at signalized intersections. In further research, drivers' attitudes, behavior and knowledge about flashing green signal should be considered and research should be conducted on a larger sample. This kind of researches should be a base for definition of the flashing green application criteria.

However, the application of a flashing green signal is not recommended in adaptive traffic control systems. Adaptive traffic control systems are the last generation of traffic signal systems that continuously make small adjustments of signal timing parameters in response to 
changing traffic demand and patterns (Mladenovic, et al. 2015). Namely, in such systems, if the flashing green signal is applied, system response time increases due to the increase of the interstage duration.

\section{Acknowledgements}

This research was carried out within the Project TR36021, "The Effects of Global Challenges on Transportation Planning and Traffic Management in Cities", financed by the Ministry of Education, Science and Technological Development of the Republic of Serbia.

\section{Ефекти трептућег зеленог светла на ефиксаност саобраћаја}

\author{
Аница Коцић, дипл.инж.саоб. \\ Универзитет у Београду, Саобраћајни факултет \\ Профр. др Никола Челар, дипл.инж.саоб. \\ Универзитет у Београду, Саобраћајни факултет \\ Јелена Кајалић, дипл.инж.саоб. \\ Универзитет у Београду, Саобраћајни факултет \\ Стаменка Станковић, дипл.инж.саоб. \\ Универзитет у Београду, Саобраћајни фракултет
}

Резиме: Трептући зелени сигнал, као део зеленог саобраћајног сигнала, указује да ће зелени сигнал ускоро завршити. Возачи имају више времена да одлуче да ли да зауставе или прођу раскрсницу јер имају претходне информације да ће жути сигнал стартовати. Примена трептућег зеленог на крају зеленог сигнала није обавезна, па је питање како инжењери могу да одлуче да користе трептуће зелено или не? Одговор на питање требало би да се заснива на истраживању трептућих зелених ефеката на ефикасност и безбедност у саобраћају на сигналним раскрсницама. Циљ овог рада је анализирати утицај трептања зелене боје на ефикасност саобраћаја одређивањем вредности ефрективног зеленог времена. Истраживање је спроведено на две раскрснице у Београду, са и без трептућег зеленог сигнала. Резултати показују да је ефективно зелено краће када се примењује трептуће зелено, због смањене употребе жутог сигнала.

Кључне речи: Трептуће зелено, ефикасност саобраћаја, ефективно зелено, семафорисана раскрсница

\section{References}

[1] Akçelik, R. (1981). Traffic Signals: Capacity and Timing Analysis: Research report ARR No. 123, seventh reprint: 1998. Australian Road Research Board.

[2] Becker, M. (1971). A study of the effect of a "flashing green" phase in traffic signals at urban intersections. Publication No.71/7, Road Safety Centre, Technion Research \& Development Foundation Ltd.

[3] Čelar, N., Stanković, S., Kajalić, J. (2018). The basics of traffic signal management, University of Belgrade, Faculty of Transport and Traffic Engineering press. (In Serbian: Osnove upravljanja svetlosnim signalima. Univerzitet u Beogradu, Saobraćajni fakultet).

[4] Factor, R., Prashker, J. N., Mahalel, D. (2012). The flashing green light paradox, Transportation Research Part F, vol. 15 (2012), pp. 279 - 288. DOI:10.1016/j.trf.2012.01.003

[5] Hakkert, A. S., Mahalel, D. (1978). Effect of traffic signals on road accidents - with special reference to the introduction of a blinking green phase, Traffic engineering \& control, vol. 19, no. 5, pp. 212-215.

[6] Knoflacher, H. (1973) Der Einfluss des Grünblinkens auf die Leistungs- fähigkeit und Sicherheit lichtsignalgeregelter Strassenkreuzungen, Schriftenreihe Strassenforschung, 8, Bundesministerium für Öffentliche Bauten.

[7] Köll, H., Bader, M., Axhausen, K. W. (2004). Driver behaviour during flashing green before amber: a comparative study, Accident Analysis and Prevention, vol. 36 (2004), pp. 273-280.

[8] Mahalel, D., Zaidel, D. M., Klein, T. (1985). Driver's decision process on termination of the green light, Accident Analysis and Prevention, vol. 17, no. 5, pp. 373 - 380.

[9] Mladenovic, M. N., Stevanovic, A., Kosonen, I., Glavic, D. (2015). Adaptive Traffic Control Systems: Guidelines for Development of Functional Requirements. In International Scientific Conference on Mobility and Transport (mobil. TUM).

[10] Shen, J., Wang, W. (2015). Effects of flashing green on driver's stop/go decision at signalized intersection, Jounal of Central South University, vol. 22, no. 2, pp. 771-778. DOI: 10.1007/s11771-015-2581-z

[11] Stanković, S., Čelar, N., Kajalić, J. (2016). Estimation of startup lost time and amber time utilization for signal timing, Third International Conference on Traffic and Transport Engineering (ICTTE), Conference Proceedings, pp. 670-674, Belgrade, Serbia.

[12] Tang, K., Wang, F., Yao, J., Sun, J. (2017). Empirical analysis and modeling of stop-line crossing time and speed at signalized intersections, International Journal of Environmental Research and Public Health, vol. 14, no. 1, pp 1-13. https://doi.org/10.3390/ijerph14010009

[13] Tang, K., Xu, Y., Wang, F., Oguchi, T. (2016). Exploring stopgo decision zones at rural high-speed intersections with flashing green signal and insufficient yellow time in China", Accident Analysis and Prevention, pp. 470-478. http://dx.doi.org/10.1016/j.aap.2016.01.011

[14] Tang, K., Xu, Y., Wang, P., Wang, F. (2015). Impacts of Flashing Green on Dilemma Zone Behavior at High-Speed Intersections: Empirical Study in China, Journal of Transportation Engineering, vol. 141,no. 7. DOl: 10.1061/(ASCE)TE.1943-5436.0000770 